\title{
EFFECT OF CASH MANAGEMENT AUTOMATION ON FINANCIAL MANAGEMENT IN MERU COUNTY GOVERNMENT
}

\author{
${ }^{1}$ Bonface Mutuma Mugambi(iD, \\ ${ }^{1}$ Department of Business Administration, Kenya Methodist University \\ Corresponding author's e-mail: bamugambi@gmail.com
}

How to cite this article: Mugambi, M., B. (2021). Effect of cash management automation on financial management in Meru County Government. Edith Cowan Journal of Procurement \& Supply Chain, 1(1), 33-38.

\section{ARTICLE INFO}

Article history:

Received Date: $3^{\text {nd }}$ Jan 2021

Revised Date: $8^{\text {th }}$ Jan 2021

Accepted Date: $18^{\text {th }}$ Jan 2021

Keywords:

Information, communication, technology adoption, financial management.

\section{A B S T R A C T}

Purpose: The main purpose of the study was to find out if ICT adoption has a significant effect on financial management in the Meru County Government. Effective public financial management has attracted attention of many scholars in identifying the best practice and how to install fiscal disciplines. In search of good governance and sound financial management, the World Bank has been on the fore front in championing this aspect. Lack of effective financial management practices hinders effective service delivery.

Design/ Methodology/Approach: Technology Acceptance Model (TAM) theory is one of the model used to explain how technology is accepted by the users. Descriptive survey research design study was used. The population for this study composed of the Meru county government staff. The sample size was 70 respondents in total, questionnaire were used as the research tool whose validity and reliability was measured accordingly. Mean and regression analysis were computed when analyzing data.

Findings: The findings established that Cash management automation enables county leadership to understand the true cost of service delivered by the county per activity; that Through Cash management automation, the county finance department is able to reconcile transactions data in real-timeOn Cash management automation the study concludes that successful cash management automation in any institution is essential due to difficulties that come with accessing credits whenever an organization is facing liquidity several constraints.

Contribution to policy and practice: From the findings on cash management automation the study recommends that automation systems should be fully implemented as it increases cash management. For Meru county Government to realize growth, investment in technology should be made in order to enhance service delivery and transparency in cash management.

Originality/Value: This study is the first of its kind to empirically explore cash management automation on financial management in Meru county government. 


\section{BACKGROUND}

Cash management is defined as the process of collecting and managing cash in an organization for, as well as using it for short-term or long term organization activities which includes investing (Kenton, 2017). Cash management involves among other things insolvency avoidance in the organization, account receivable and payable management, working capital management and long term commitment as they fall due (Abubakar, 2013). The null hypothesis $\left(H_{0}\right)$ predicted that the cash management automation has no significant influence on the financial management in Meru County government.

Cash management involves the process of cash collection, monitoring of cash and its application in investment activities. It is one of the key element for ensuring a county financial stability and solvency (Hansen, 2015). The management of cash focuses at ensuring adequate cash is maintained by the county and any surplus is put into the correct use. Business entities have the duty of ensuring that the entities don't overuse overdrafts as the means of finance.

A Successful cash management exercise in any institution is essential due to difficulties that come with accessing credits whenever an organization is facing liquidity constrains (Kenton, 2017). In the public sector, cash management is a task which always has to be viewed in a serious angle otherwise even the worker may go without sallies due to the nature of cash accounting (World Bank, 2018). The accounting model adopted in the public sector, to a certain extent helps in managing the issue to deal with cash management since most of the levies are paid at the end of the period they are consumed.

\section{Research Problem}

IFMIS was introduced to mitigate the government against loss of revenue against unauthorized expenditure. The IFMIS has promoted transparency, accountability and responsiveness of cash management. Other benefits include curtailing wasteful spending and corruption, enhancing controls and audit procedures as well as strengthening cash management and reporting (Selfano, Peninah \& Sarah, 2014). Lack of cash management automation and proper financial management has led to the woes that are being experienced in the County governments in terms of lack of confidence in the existing governance. Since these governments are funded by tax systems it is only fair that the system is efficient and friendly throughout till the enjoyment of the public services to the tax payer. Unfortunately, this is yet to be seen. There exists scarce studies on how cash management automation is affecting financial management on key areas like revenue collection and related functions which are not directly integrated to IFMIS.This study is set out to investigate cash management automation in financial management practices where it will specifically assess the effects of automating the cash management on prudent financial management in Meru County Government, Kenya.

\section{LITERATURE REVIEW}

A Successful cash management exercise in any institution is essential due to difficulties that come with accessing credits whenever an organization is facing liquidity constrains (Kenton, 2017). In the public sector, cash management is a task which always has to be viewed in a serious angle otherwise even the worker may go without sallies due to the nature of cash accounting (World Bank, 2018).

Cash management automation is necessary because there are mismatches between the timing of payments and the availability of cash. Even if the annual budget is balanced, with realistic revenue and expenditure estimates, in-year budget execution will not be smooth, since both the 
timing and seasonality of cash inflows and of expenditures can result in conditions of temporary cash surpluses or temporary cash shortfalls (Lienert, 2013).

Cash management automation forms an integral part of financial management. Hence, it is considered as part of the scope of a good working capital management in county government (Brealey, Myers \& Allen, 2018). Pandey (2010) supports that, cash management automation in the modern world involves two simple rules; first, speed up cash collection (Cash Inflow) which minimizes collection float, and slow down cash disbursement (Cash Outflow) which maximizes disbursement float as a way of ensuring proper financial management.

Uwalomwa and Egbide (2016) claims that cash management automation entails taking the needed precautionary measures to ensure that adequate cash levels are maintained in the county government so that the operational requirements could be met. This claim is seconded by Aliet (2014) who indicated that, cash management automation is the management of cash to maximize the cash held in the county that is not invested in buying inventory or fixed assets. In other words, it is the management of cash to avoid the risk of the county becoming insolvent.

Nkeobuna \& Ugoani (2017) did a study on implementation of IT in the government of Nigeria and established that most of financial transaction in the country has migrated to an integrated platform. The main objective of the study was to assess the extent of financial integration in the country with a view of improving on cash management. The study found out that even though the government was using Information systems on all its cash transactions, there was a challenge to those who pay their money on daily bases. It was also established that there were gaps when it comes to the real service being offered, by a measure of the service the quality was low. The study further revealed that all other units of the government not all of were committed in utilizing Information Systems and ICT in carrying out their operations as some were found not basing their decision making on ICT based records despite their availability.

Mugambi (2018) did a study on effect of implementation of information system on financial management in Kenya. This study revealed that there were various systems in use especially in county government where a combination of IFMIS and LAIFORM are being used to manage financial matters. From the respondents who were interviewed, there was a general agreement that positive financial controls with the influence of ICT have been achieved. The findings of the study gave a view that adoption of ICT had indeed enhanced tighter financial control within Meru county government. However there were inherent challenges facing the implementation of ICT which the Government is addressing up to the point of the study like funding.

\section{MATERIALS AND METHODS}

Descriptive research design was adopted in describing the nature of ICT adoption in Meru County. The study was concerned with predictions, description of facts and features (Kothari, 2014) regarding financial management and cash management automation. Data was gathered and analyzed by use of descriptive statistics method. The descriptive statistical method (mean, standard deviation) aided in describing the data and determining the respondents' degree of conformity with the diverse statements under each factor. To measure the reliability of the data collection instruments an internal consistency technique Cronbach's alpha was computed using SPSS. The Content Validity Index was used to determine the validity. The pre-testing involved questionnaires from cash management staff in Tharaka Nithi county government. The data obtained from these respondents was analyzed using regression analysis. Data obtained from the open ended questions in the questionnaire was subjected to ANOVA data analysis method. Tables were used to present the data. The relationship between the study variables was established by the use of multiple regressions. 


\section{RESULTS}

Regression analysis was run to show the nature of the relationship between financial management in the public sector in Kenya and the independent variables. Diagnostic test was conducted in order to reduce the data to a meaningful and manageable set of factors (Sekaran, 2006).The approach involves condensing the information contained in a number of original variables into a smaller set of dimensions (factors) with a minimum loss of information. Table 1 the correlation analysis.

Table 1 Correlation Analysis

\begin{tabular}{|c|c|c|c|c|c|c|c|}
\hline Statements & 1 & 2 & 3 & 4 & 5 & Mean & Std \\
\hline $\begin{array}{l}\text { Cash management automation } \\
\text { enables transfer funds efficiently } \\
\text { and with certainty in the county }\end{array}$ & $\begin{array}{l}8(11 \\
\%\end{array}$ & $9(12.2 \%)$ & $16(22.5 \%)$ & $17(24.1 \%)$ & $22(31.2 \%)$ & 5.13 & 1.93 \\
\hline $\begin{array}{l}\text { Cash management automation } \\
\text { enables organization to structure } \\
\text { funds repositories so that the } \\
\text { government always knows what } \\
\text { funds are at its disposal and } \\
\text { where they are and that it can } \\
\text { move these funds at will }\end{array}$ & $6(9 \%)$ & $10(13.7 \%)$ & $18(26.1 \%)$ & $15(22 \%)$ & $21(30 \%)$ & 3.94 & 0.59 \\
\hline $\begin{array}{l}\text { Cash management automation } \\
\text { seek to improve execution by } \\
\text { providing timely and accurate } \\
\text { data for cash management and } \\
\text { decision making }\end{array}$ & $6(8 \%)$ & $12(17.1 \%)$ & $14(20 \%)$ & $20(28 \%)$ & $19(27 \%)$ & 4.12 & 1.28 \\
\hline $\begin{array}{l}\text { Cash management automation } \\
\text { seek to enhance confidence and } \\
\text { credibility of the cash through } \\
\text { greater transparency of } \\
\text { information }\end{array}$ & $3(4 \%)$ & $11(15.2 \%$ & $16(23.5 \%)$ & $22(31.0 \%)$ & $19(26.8 \%)$ & 3.55 & 1.86 \\
\hline $\begin{array}{l}\text { Automation has enabled high } \\
\text { level of cash accountability }\end{array}$ & $6(8 \%)$ & $8(11.4 \%)$ & $17(24.2 \%)$ & $20(28 \%)$ & $21(30.8 \%)$ & 3.65 & 1.98 \\
\hline $\begin{array}{l}\text { Cash management automation } \\
\text { enables county leadership to } \\
\text { understand the true cost of } \\
\text { service delivered by the county } \\
\text { per activity }\end{array}$ & $\begin{array}{l}7(10 \\
\%)\end{array}$ & $12(17.8 \%)$ & $15(21.5 \%)$ & $\begin{array}{l}18(25.7 \%) \\
\%\end{array}$ & $18(25 \%)$ & 4.04 & 1.16 \\
\hline $\begin{array}{l}\text { Through Cash management } \\
\text { automation, the county finance } \\
\text { department is able to reconcile } \\
\text { transactions data in real-time }\end{array}$ & $\begin{array}{l}5(7.8 \\
\%)\end{array}$ & $9(13 \%)$ & $16(23 \%)$ & $20(29 \%)$ & $20(28 \%)$ & 4.13 & 1.66 \\
\hline Composite Mean and Std & & & & & & 4.16 & 1.8 \\
\hline
\end{tabular}

From the findings in Table 1, respondents agreed to the statement that the Cash management automation enables transfer funds efficiently and with certainty in the county; That Cash management automation enables organization to structure funds repositories so that the government always knows what funds are at its disposal and where they are and that it can move these funds at will,; That Cash management automation seek to improve execution by providing timely and accurate data for cash management and decision making.; that Cash management automation seek to enhance confidence and credibility of the cash through 
greater transparency of information.; that Automation has enabled high level of cash accountability; that Cash management automation enables county leadership to understand the true cost of service delivered by the county per activity; that Through Cash management automation, the county finance department is able to reconcile transactions data in real-time as indicated by a mean of $5.13 ; 3.94 ; 4.12 ; 3.55 ; 3.65 ; 4.04 ; 4.13$ and a composite mean 4.16 respectively.

This study collates with literature review by Mugambi (2018) who did a study on effect of implementation of information system on financial management in Kenya. This study revealed that there were various systems in use especially in county government where a combination of IFMIS and LAIFORM are being used to manage financial matters. This means that Cash management automation plays a key role in financial management in Meru county government.

\section{Regression Analysis}

Table 2 Regression Results

\begin{tabular}{lccccc}
\hline \hline & & B & Std. Error & t & Sig. \\
\hline (Constant) & 8.806 & 3.843 & & 2.292 & 0.026 \\
Product strategy & 0.681 & 0.138 & 0.553 & 4.928 & 0.000 \\
\hline
\end{tabular}

Since the predictor of financial management in Meru County government (cash management automation, X1; had identical Likert scales, and considering that the constant value is significant in this model. As shown in Table 2 the study therefore used the B-coefficients rather than the beta coefficients in interpreting the regression weights. Consequently, the value of regression weights shown in Table 3 indicate that the financial management in Meru County government will always exist at a certain significant minimum $(\beta 0=3.181, P<.000)$. The hypothesized model $(Y=B 0+B 4 X 4+e)$ now quantifies the strength of the relationships presumed in this study. Precisely, the model shows that the financial management in Meru County government is (cash management automation) + 3.181)). In this model, 3.181 is a baseline score that is unrelated to any other variables which means that it is the same 3.181 points for each variable; for example, on average, 1 point higher on budgeting process automation score 0.066 points higher on financial management in Meru County government. The resulting model in this study is:

$$
Y=3.181+-0.096 \times 1+e
$$

This finding agrees with IMF (2006) findings on use of IFMIS in financial management. The study found that financial reporting had improved due to use of IFMIS. This also agree with USAID (2008) that reporting systems have been improved by use of a single reliable platform of financial reporting since IFMIS tracks financial events and summarize reports effectively. The study findings show that there was timely preparation of budgets using IFMIS. This echoes IMF recommendations for use of a comprehensive cash management system for prompt service delivery.

As was noted by Bill (2001), although automated systems facilitates many controls during transaction process, the study found that internal controls faced a number of challenges as the system was not water tight in controlling all the financial processes. Heidenholf (2002) had noted that the difficulties faced by governments in completing projects were related to lack of effective financial management systems. The study found that through application of IFMIS especially on budgeting, and in reporting, a number of projects initiated through the system have been successfully completed and on time. 


\section{CONCLUSION}

On Cash management automation, the study concludes that successful cash management automation in any institution is essential due to difficulties that come with accessing credits whenever an organization is facing liquidity constrains. In the public sector, cash management is a task which always has to be viewed in a serious angle otherwise even the worker may go without sallies due to the nature of cash accounting. The cash management model adopted in the public sector, to a certain extent helps in managing the issue to deal with cash management since most of the levies are paid at the end of the period they are consumed.

\section{Areas for Further Research and recommendations}

From the findings on cash management automation, the study recommends that automation systems should be fully implemented as it increases cash management. For Meru county Government to realize growth, investment in technology should be made in order to enhance service delivery and transparency in cash management. The study also recommends that government should make the adoption of technology easy by reducing cost of acquiring new equipment and other innovations.

The study recommends that the hospital management should maintain and encourage the accountants and other relevant employees to prepare cash budget always for this will help in making purchases for goods and services only budgeted for. Based on the findings and conclusions the study suggests that Meru county government management should maintain proper books of accounts for this is one way will help track movements and use of funds by the county.

\section{REFERENCES}

Abubakar, S. S. (2013). Cash management practices in public sector enterprises. Facilities, 33(11/12), 736-751.

Bill (2001). Case study research: Design and methods (2nd ed.). Beverly Hills: Sage Publishing, New Delhi.

Brealey, A. R., Myers, C. S \&Allen, F. (2018). Principles of Corporate Finance, New York:McGraw-Hill/Irwin.

Cooper, D. and Schindler, P. (2011) Business Research Methods. 11th Edition, McGraw Hill, Boston

Dorotinsky, B. (2003). Implementing financial management information system projects: TheWorld Bank experience, retrieved on 6the match 2017 fromhttp://blog-pfm. imf.org/AIST2/Dorotinsky.

GoK. (2011). Integrated Financial Management Information System (IFMIS) IFMIS ReEngineering. From Modular, to Full Cycle End-To-End Processes, Strategic Plan 20112013. Nairobi: Government Printer.

Hansen AS, et al. (2015) High-throughput microfluidics to control and measure signaling dynamics in single yeast cells. Nat Protoc 10(8):1181-97.

Heidenhof, G.(2002). Design and Implementation of Financial Management Systems: An African Perspective. Africa Region Working Paper Series No. 25. 
Kenton, W. (2017). Effect of Automation of Financial Management Systems on Financial Performance of County Government of Trans-Nzoia. International Journal of Management and Commerce Innovations, 4(2), 352-359.

Kothari, C. R. (2007). Research Methodology (2nd ed. edition). New Delhi: New Age International Pvt Ltd Publishers.

Kothari, C. R. (2014). Research Methodology (2nd ed. edition). New Delhi: New Age International Pvt Ltd Publishers.

Lienert, I. (2013). Modernizing Cash Management. Fiscal Affairs Washingtom D.C: World Bank;I nternational Monetary Fund.

Mugambi, K. W., Fridah, M., \& Theuri, S. (2014). The Challenges Encountered By County Goverments In Kenya During Budget Preparation. Journal of Business and Management, $16(2), 128-134$.

Nkeobuna, J., \& Ugoani, N. (2017). Effect of Weak Public Financial Management on Public Sector Management and Sustainable Development in Nigeria. American Journal of Environment and Sustainable Development Effect, 2(3), 23-32.

Orodho, J. A. (2012). Techniques of writing research proposals and reports in education and social sciences. Nairobi. Kanezja publishers.

Pandey, I.M. (2010). Financial management (6th Ed.).New Delhi: Vikas Publishing House PVT Ltd.

Peterson, S. C. Kinyeki, J. Mutai, Kipsang, S. W. (2008). Computerizing Accounting Systems in Developing Bureaucracies: Lessons from Kenya. Public Budgeting and Finance, Vol. 16(4). Winter, pp. 45-58.

Sekaran, U. (2006). Research methods for business: A skill building approach. John Wiley \& Sons.

Selfano, O. F., Peninah, A., \& Sarah, C. (2014). Integrated Financial Management Information System and Its Effect on Cash Management in Eldoret West District Treasury, Kenya. International Journal of Business and Social Science,5(8).

World Bank. (2018). Alternative Paths to Public Financial Management and Public Sector Reform Experiences from East Asia. Washington DC: International Development in Focus. 